\title{
WATER REQUIREMENTS FOR CARROT CROP WITH SPRINKLER IRRIGATION UNDER RUSSIAN CONDITIONS
}

\section{Abdeltawab M. I. Zedan' ${ }^{1} *$, Pchyolkin Victor ${ }^{2}$, Mohamed A. Rashad ${ }^{3}$ and Ahmed F. Khedr ${ }^{3}$}

${ }^{1}$ Assoc. Prof. of Irrigation and Drainage Eng., Ag. Eng. Dept., Fac. of Ag., Zagazig U., Egypt.

${ }^{2}$ Prof. of land reclamation and Irrigation, Russian State Agrarian U., Moscow, Russia.

${ }^{3}$ Assoc. Prof. of Irrigation and Drainage Eng., Ag. Eng. Dept., Fac. of Ag., Suez Canal U., Egypt.

* E-mail: Mto252000@yahoo.com

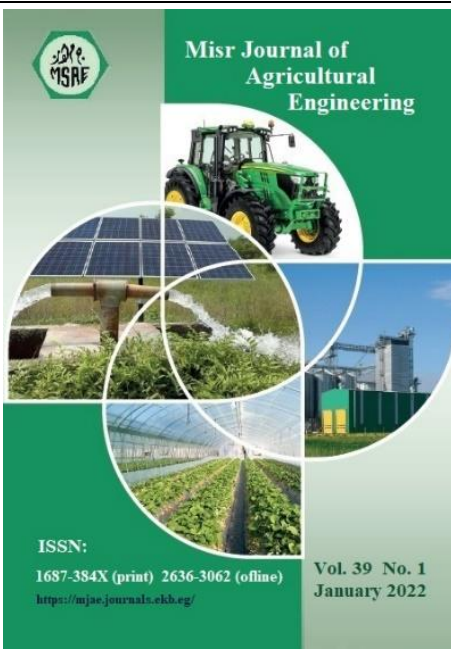

() Misr J. Ag. Eng. (MJAE)

Keywords:

Carrot; Water requirements; Sprinkler irrigation; Deficits air humidity.

\begin{abstract}
This work aims to calculate of water requirements for carrot under sprinkler irrigation in sandy loam soil at Selkovo village, Sergiev Posad District, Moscow Region, Russia, situated at $56^{\circ}$ $35^{\prime} \mathrm{N}$ latitude, and $38^{\circ} 09^{\prime} \mathrm{E}$ longitude. The average yields were 54 ton/ha for the first season and 58.8 ton/ha for the second season for carrot. The total water requirements were $344 \mathrm{~mm}$ $\left(3440 \mathrm{~m}^{3} / \mathrm{ha}\right)$ and $338 \mathrm{~mm}\left(3380 \mathrm{~m}^{3} / \mathrm{ha}\right)$, during two successive seasons respectively. The average of temperature of July $17.8^{\circ} \mathrm{C}$ at the average of relative humidity of $61 \%$. The relationships between water requirements ( $E, \mathrm{~mm} /$ day) and deficits relative humidity (ds, mbar) having the following formula: $E=a d s^{b}(1)$ Where, $a, b$ - empirical coefficients of the regression equation. At using experimental data through the two seasons of carrot. That equal $a=1.06$ and $b=0.86$ then the relation become $(E=$ $1.06 \mathrm{ds}^{0.86}$ ) and the correlation coefficient was $0.959 \pm 0.073$. This means that in $91.9 \%$ of the water consumption of carrot variations in these conditions due to variations in deficits air humidity. For calculating carrot water requirements under sprinkler irrigation was found as $E=K_{F} K_{C} a d s^{b}$ considering $K_{F}-$ Coefficient depending on wetting pattern under sprinkler and $K_{C}-$ Crop coefficient. The experimental data for growth seasons during calculation the crop coefficient of carrot through growth season was found as $K_{C}=0.649+0.128 t_{r}-0.011 t_{r}^{2}$ considering tr as decade number.
\end{abstract}

\section{INTRODUCTION}

$\mathrm{T}$

The central region of the Non-Black Soils Zone of the Russian Federation has large areas of agricultural land, which make up more than 20 million hectares. A significant part of these lands (57\%) is located on sod-podzolic soils, $30 \%$ of which are confined to watershed areas. The intensification of agricultural production on these lands is of great importance for Russia. One of the factors of intensification of agricultural production is irrigation. 
In the central region of Russia, you can grow the main crops, including carrots. It should be noted that years (1 time in 6 years) and vegetation periods are observed in this region 50 days, when there is not enough natural rainfall. In these years and periods of vegetation, the soil is dried up and is not enough for optimal growth and development of crops. This situation with natural precipitation causes the need for additional irrigation of the calculated soil layer. When developing projects of irrigation systems, it is necessary to calculate the regime of irrigation of carrots in this region of the Non-Black Soils Zone of Russia. (Pchyolkin, 2013), (Shuravilin, 2006, 2013), (Vaneyan and Lesser, 2010).

There are a number of methods for calculating the regime of irrigation of vegetable crops for the Non-chernozem zone of the Russian Federation (Tsipris, 1973), (Zimin, 1989), (Pchyolkin and Zimin, 2003), (Shelkovkina, 2004). It should be noted that these calculation methods were developed for the conditions of scientific research. Their use in other natural and climatic conditions necessitates clarification and adjustment.

Water consumption of crops is one of the main expenditure components of the water balance in determining the irrigation regime. A number of authors have developed formulas for calculating the water consumption of crops, as in Russia (Alpatiev, 1971), (Ivanov, 1954), (Pchyolkin, 2013, 2015), and others, both abroad, (Klatt, 1970), (Badr, et al., 2006). Known formulas, including biological and other coefficients, were developed in certain climatic zones for certain crops, therefore, their use in other conditions necessitate appropriate adjustments and refinements (Pchyolkin and Zimin 2003). A significant number of existing water consumption calculation formulas do not take into account soil moisture. It should be noted that biological coefficients for decade periods and coefficients allowing taking into account the decrease in soil moisture when growing canteen carrots in the conditions of sod-podzolic soils of watershed territories are absent.

There are three major groups of irrigation systems: surface, sprinkler and drip (microirrigation). Under sandy loam soil condition, sprinkler irrigation is the artificial application of water to agriculture lands in order to insure adequate for crop growth. It is considered as highly efficient system because it allows small but frequent application of water with minimum losses. Fertilizer or chemical amendment could be efficiently applied to plants.

Evapotranspiration data for agricultural crops has become increasingly important in irrigation management as well as in water resources management. It is dependent not only on the meteorological elements, but also on factors related to the crop and to the soil availability and soil environment. A knowledge of water requirements is necessary in planning farm irrigation system and improving efficient use of water and fertilizers, and the proper water management requires not only accurate determination of crop water requirements, but also we must know when and how much water should be applied.

The volume of water required for optimal growth and development of crops during their growing season is called water consumption or total evaporation. Water consumption includes the sum of two vapors: physical evaporation from the soil surface and transpiration of plants. Evaporation from the soil surface is affected only by climatic conditions, and transpiration and climatic conditions, as well as internal factors of plants. 
A number of researchers (Pchyolkin, 2015, Aleksankin, 1980, Ivanov, 1954, Romanova, et al., 1983) have shown that evaporation from the soil surface is both a separate part of the total evaporation during the non-growing season, and its integral part during the vegetation period of plants. Formulas for calculating evaporation from the soil surface without vegetation are used to calculate drainage and water balance in the pre-sowing period. Currently, a significant number of methods for calculating the total evaporation of crops have been developed. These include: the method of water balance, the method of turbulent diffusion, the method of heat and water-heat balance, empirical formulas.

The objective of this work was to conduct water balance studies and calculated of water requirements for carrot (Chantenay Royal) in sandy loam soil with sprinkler irrigation system on sod-podzolic soils of the watershed areas of the Moscow Region under Russian conditions.

\section{MATERIALS AND METHODS}

Field experiments were carried out in Sandy loam soil during two successive seasons (2018/2019) at the (OMP) «Dubna» experimental station, RGAU-Moscow Agricultural Academy named after K.A. Timiryazev, Moscow Institute of Environmental Engineering named after A.N. Kostyakov, located in the south-eastern part of the Moscow Region, Sergiev Posad District, Selkovo village, situated at $56^{\circ} 35^{\prime} \mathrm{N}$ latitude, and $38^{\circ} 09^{\prime} \mathrm{E}$ longitude. Chemical, physical and hydrophysical properties of this soil were determined according to (Dokuchaeva, 2002) and shown in tables $(1,2,3)$. Soil mechanical analysis was carried out using the international pipette method according to Jacobs et al., (1971). The bulk density of soil was determined using undisturbed soil cores according to Klute (1986). Soil moisture, maximum hygroscopic soil moisture, and soil moisture with wilting point were determined according to (GOST R 2013).

The sprinkler irrigation system had the following characteristics, the kind of used Rain Bird Spray (Model 1812) with discharge $0.84 \mathrm{~m}^{3}$ /hour, operating pressure, $2 \mathrm{~atm}$, case height, 40 $\mathrm{cm}$, stem height, $30 \mathrm{~cm}$, watering angle, $360^{\circ}$, kind of nozzle U-15, operating radius, $4.5 \mathrm{~m}$. Water was supplied to the spray through an irrigation network; for this purpose, a collector pipe $32 \mathrm{~mm}$ in diameter, coupled with irrigation pipelines (PT) with a diameter of $20 \mathrm{~mm}$, was laid underground. Water for irrigation was taken from the village water supply. At the beginning, before irrigation, water was supplied to a plastic tank with a volume of $3 \mathrm{~m}^{3}$, then it flows through the connecting pipe to the pump, and then it is supplied to the sprayers under pressure. The pump station is mounted in a reinforced concrete well with a diameter of $1.5 \mathrm{~m}$ and a depth of $2.0 \mathrm{~m}$. The pump was used (Grundfos CR5-9), with a pressure of $50 \mathrm{~m}$, a flow rate of $4.5 \mathrm{~m}^{3} / \mathrm{h}$.

Irrigation water was applied at rates based on (100\%) from the crop evapo-transpiration (ETc) calculated according to (Smith, 1992). Carrot was planted on may month and carrots respond well to organic fertilizers, in this regard, organic fertilizers was added to all plots with rate of 100 ton/ha. Carrot has a high requirement for soil fertility. Maximum yields of carrots are closely associated with added of optimal doses of fertilizer, in the spring, $\mathrm{N}_{100}, \mathrm{P}_{80}, \mathrm{~K}_{150}$. Fertilizers were applied in 3 doses: the first time during sowing (50\% fertilizer) and the second and third fertilizing (25\% fertilizer each), chemical fertilizers were applied as 
following: ammonium sulphate at rate of $714 \mathrm{~kg} / \mathrm{ha}$ potassium sulphate at rate of $238 \mathrm{~kg} / \mathrm{ha}$ and super phosphate at rate of $357 \mathrm{~kg} / \mathrm{ha}$. The definition of fertilizer doses ware carried out according to the dependence (Kruzhilin, 1977).

Soil sampling for moisture content were taken from different sites locations around the sprinkler at 10, 20, 30, 40 and $50 \mathrm{~cm}$ depth. Soil moisture values were measured once every 5 days, as well as before irrigation and after rainfall and irrigation through the three stages of carrot growth season used the device TRIME-FM made in Germany for determined soil moisture content.

Table (1): Physical, chemical and hydrophysical properties of sandy loam soil in the experiment site during two seasons.

\begin{tabular}{|c|c|c|c|c|c|c|c|c|}
\hline Soil layer & Particle & $\begin{array}{c}\text { ze dist } \\
\%\end{array}$ & oution* & Texture class* & $B . D^{* *}$ & $O . M$ & F.C & $* * * P W P$ \\
\hline $\mathrm{cm}$ & Sand & Silt & Clay & & $\mathrm{g} / \mathrm{cm}^{3}$ & $\%$ & $\%$ & $\%$ \\
\hline $0-20$ & & & & & 1.37 & 2.20 & 7.3 & 1.1 \\
\hline $20-40$ & & & & & 1.57 & 0.40 & 6.6 & 0.9 \\
\hline $40-60$ & 83 & 10.2 & 6.8 & Sandy loam & 1.54 & 0.30 & 6.8 & 0.9 \\
\hline $60-80$ & & & & & 1.42 & 0.20 & 6.6 & 1.0 \\
\hline $80-100$ & & & & & 1.73 & 0.20 & 5.0 & 0.8 \\
\hline
\end{tabular}

*Classification of the International Society of Soil Science, **B.D is the soil bulk density, ***PWP permanent wilting point.

Table (2): Chemical characteristics of the experimental soil.

\begin{tabular}{|c|c|c|c|c|c|c|}
\hline $\mathrm{PH}$ & $\mathrm{P}_{2} \mathrm{O}_{5}$ & $\mathrm{~K}_{2} \mathrm{O}$ & $\mathrm{N}-\mathrm{NH}_{4}$ & $\mathrm{~N}-\mathrm{NO}_{3}$ & $\mathrm{Ca}$ & $\mathrm{Mg}$ \\
\hline \multirow{2}{*}{6.8} & \multicolumn{4}{|c|}{$\mathrm{mg} / \mathrm{kg}$} & \multicolumn{2}{|c|}{$\mathrm{meq} / 100 \mathrm{~g}$ soil } \\
\hline & 326 & 325 & 1.8 & 34.7 & 10.6 & 2.2 \\
\hline
\end{tabular}

Table (3): Chemical characteristics of irrigation water.

\begin{tabular}{cccccccc}
\hline $\mathrm{PH}$ & $\mathrm{N}-\mathrm{NH}_{4}$ & $\mathrm{~N}-\mathrm{NO}_{3}$ & $\mathrm{~K}$ & $\mathrm{Ca}$ & $\mathrm{Mg}$ & $\mathrm{Fe}$ & $\mathrm{Zn}$ \\
\hline \multirow{8}{*}{$6.5-7.7$} & \multicolumn{7}{c}{$\mathrm{mg} / \mathrm{L}$} \\
\cline { 2 - 9 } & 1.77 & 0.80 & 4.55 & 74.2 & 26.0 & 0.178 & 2.15 \\
\hline
\end{tabular}

In the experiment were measured components of the water balance equation of experimental plot on which investigated soil moisture content is $(\mathrm{mm})$ :

$$
\Delta W=\mathrm{I}+\mathrm{P}-\mathrm{ETc} \pm \mathrm{Dp}
$$

Where:

$$
\begin{aligned}
& \Delta W-\text { Change of soil moisture content, } \quad \Delta W=\mathrm{W}_{\mathrm{F}}-\mathrm{W}_{\mathrm{B}} \\
& \mathrm{W}_{\mathrm{F}}-\text { Final soil moisture content, } \mathrm{mm} ; \\
& \mathrm{W}_{\mathrm{B}}-\text { Beginning soil moisture content, } \mathrm{mm},
\end{aligned}
$$


P - Precipitation, $\mathrm{mm}$,

I - Irrigation, mm;

ETc - Crop evapotranspiration, $\mathrm{mm} /$ decade $;($ decade $=10$ days period $)$

Dp - Deep percolation, $\mathrm{mm}$.

Total water requirements ware determined from the water balance equation as an unknown with the measured values, $\mathrm{m}$ and $\mathrm{q}$. Water balance $(\mathrm{mm})$ that calculated a layer of soil $(0-50 \mathrm{~cm})$.

\section{RESULTS AND DISCUSSION}

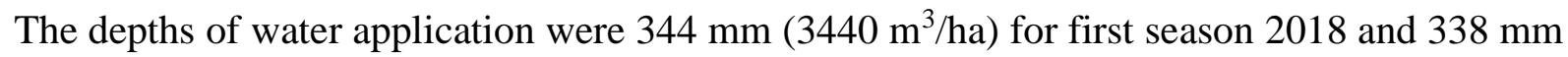
(3380 $\mathrm{m}^{3} / \mathrm{ha}$ ) for second season 2019 , while the average yields were 54 and $58.8 \mathrm{ton} / \mathrm{ha}$ for two seasons 2018 and 2019 respectively. The yield increments may be attributed to the increase of leaves number per plant which developed photosynthesis process. This leads to improve fruit number per plant. Also, carrot plant is classified belongs to cold-resistant crops. Carrots are very demanding on soil moisture, especially during seed germination and in the initial period of growth, water applied rates throughout the growing seasons shown in table 4 . This finding was in agreement with Pchyolkin, 2015, Averyanov, (2015), Pchyolkin and Zimin, (2003). The seeds of the carrot germinate at a temperature of 3-5 ${ }^{\circ} \mathrm{C}$, but sowing is more correct to carry out at a temperature of $+6 \ldots+8{ }^{\circ} \mathrm{C}$. The optimum temperature for the growth and development of carrots, and, therefore, to extract the highest productivity, should be $+18 \ldots+25{ }^{\circ} \mathrm{C}$. The seeds of the carrot were soaked 2 days before sowing, and on the day of sowing, they were dried to the position of not gluing the seeds.

Table (4): Water applied rates throughout the growing seasons of carrot.

\begin{tabular}{ccccc}
\hline \multirow{2}{*}{ Period, day } & \multicolumn{2}{c}{ Water applied $\mathrm{mm} /$ period } & \multicolumn{2}{c}{ Water applied $\mathrm{m}^{3} / \mathrm{ha}$} \\
\cline { 2 - 5 } & first season & second season & first season & second season \\
\hline 32 & 112 & 110 & 1120 & 1100 \\
30 & 123 & 121 & 1230 & 1210 \\
47 & 109 & 107 & 1090 & 1070 \\
\hline Total & 344 & 338 & 3440 & 3380 \\
\hline
\end{tabular}

The results in table 5 showed that the rainfall during the growing seasons was 204 and 282 $\mathrm{mm}$, and the depths of irrigation rate were 174 and $204 \mathrm{~mm}$ respectively. While water requirements were $344 \mathrm{~mm}$ for first season and $338 \mathrm{~mm}$ for second season. Infiltrations rates were 88 and $62 \mathrm{~mm}$, and $\Delta \mathrm{W}$ (change of soil moisture content) were 24 and $8 \mathrm{~mm}$ during the growing seasons respectively.

Comparative analysis of actual water requirements of carrot and calculated by different methods during the growing seasons.

Currently there are a significant number of computational methods for the determination of water requirements with Russian most widely used formula of the following authors: Alpatiev, 1971, Ivanov, 1954, Klatt, 1970, Blaney-Kridll, 1986, Tsipris, 1973 and others, Klimko, Kanziber, Ermolina 1990. 
Table (5): Water balance $(\mathrm{mm})$ calculated a layer of soil $(0-50 \mathrm{~cm})$ for growing seasons.

\begin{tabular}{|c|c|c|c|c|c|c|c|c|}
\hline \multicolumn{9}{|c|}{ Water Balance for the first season } \\
\hline \multicolumn{4}{|c|}{$\Delta W=\mathrm{I}+\mathrm{P}-\mathrm{ETc} \pm \mathrm{Dp}$} & \multicolumn{5}{|c|}{$\Delta W=\mathrm{W}_{\mathrm{F}}-\mathrm{W}_{\mathrm{B}}$} \\
\hline \multicolumn{2}{|r|}{ Data } & \multicolumn{2}{|c|}{ Soil moisture content $(\mathrm{mm})$} & \multicolumn{5}{|c|}{ The elements of water balance $(\mathrm{mm})$} \\
\hline Month & No. of decade & $\mathbf{W}_{\mathbf{B}}$ & $\mathbf{W}_{\mathbf{F}}$ & $\Delta \mathbf{W}$ & $\mathbf{P}$ & I & Dp & E (mm/decade) \\
\hline May & 3 & 126 & 131 & +5 & 29 & 10 & -5 & 29 \\
\hline \multirow{3}{*}{ June } & 1 & 131 & 151 & +20 & 49 & 0 & -8 & 21 \\
\hline & 2 & 151 & 164 & +13 & 74 & 0 & -30 & 31 \\
\hline & 3 & 164 & 155 & -9 & 16 & 25 & -10 & 40 \\
\hline \multirow{3}{*}{ July } & 1 & 155 & 167 & +12 & 0 & 59 & -4 & 43 \\
\hline & 2 & 167 & 170 & +3 & 35 & 5 & -5 & 32 \\
\hline & 3 & 170 & 152 & -18 & 25 & 20 & -5 & 58 \\
\hline \multirow{3}{*}{ August } & 1 & 152 & 151 & -1 & 11 & 40 & -1 & 51 \\
\hline & 2 & 151 & 152 & +1 & 10 & 15 & -2 & 22 \\
\hline & 3 & 152 & 150 & -2 & 33 & 0 & -18 & 17 \\
\hline \multicolumn{4}{|c|}{ Total, mm } & +24 & 282 & 174 & -88 & 344 \\
\hline \multicolumn{9}{|c|}{ Water Balance for the second season } \\
\hline \multicolumn{2}{|r|}{ Data } & \multicolumn{2}{|c|}{ Soil moisture content $(\mathbf{m m})$} & \multicolumn{5}{|c|}{ The elements of water balance ( $\mathrm{mm})$} \\
\hline Month & No. of decade & $\mathbf{W}_{\text {B }}$ & $\mathbf{W}_{\mathbf{F}}$ & $\Delta \mathbf{W}$ & $\mathbf{P}$ & $\mathbf{I}$ & Dp & E (mm/decade) \\
\hline May & 3 & 152 & 168 & +16 & 47 & 13 & -13 & 31 \\
\hline \multirow{3}{*}{ June } & 1 & 168 & 157 & -11 & 9 & 26 & -5 & 41 \\
\hline & 2 & 157 & 136 & -21 & 9 & 20 & -12 & 38 \\
\hline & 3 & 136 & 125 & -11 & 4 & 36 & -10 & 41 \\
\hline \multirow{3}{*}{ July } & 1 & 125 & 133 & +8 & 42 & 13 & -4 & 43 \\
\hline & 2 & 133 & 138 & +5 & 20 & 27 & -5 & 37 \\
\hline & 3 & 138 & 156 & +18 & 43 & 5 & -10 & 20 \\
\hline \multirow{3}{*}{ August } & 1 & 156 & 170 & +14 & 16 & 25 & -1 & 26 \\
\hline & 2 & 170 & 160 & -10 & 4 & 24 & -2 & 36 \\
\hline & 3 & 160 & 160 & 0 & 10 & 15 & 0 & 25 \\
\hline \multicolumn{4}{|c|}{ Total, mm } & +8 & 204 & 204 & -62 & 338 \\
\hline
\end{tabular}

Theses formulas were calculated water requirements of carrot. The results and data of the experiments were shown in figures 1 and 2. Analysis of figures shows that the root zone and soil moisture content affects the water requirements of carrot.

Water requirements (experimental data) appropriate soil moisture located within the boundaries of water requirements was calculated by known formulas. Between the 
experimental data and calculated according to the formula to make comparative analysis for two seasons respectively.

A large number of methods are known for calculating the total evaporation of vegetable crops. In the Russian Federation, for the calculation of total evaporation, the methods of the following scientists were widely used: Alpatiev, Ivanov, Clatt, Blaney-Kridll, Tsipris and others, Klimko, Kanziber, Ermolina.

Using the formulas of famous scientists, calculations were made of the total evaporation of carrots on sod-podzolic soils of the watershed areas of the Moscow Region. The calculation data and the results of studies were given in figures 1 and 2.

The calculation results by the method of Alpatiev show that there is low convergence associated with the use of a constant bioclimatic coefficient that does not take into account the biological conditions of carrots during the growing season. The differences between the calculated values of total evaporation and those obtained experimentally during the growing seasons were from $3.5 \%$ to $35.3 \%$ and $14 \%$ to $34.7 \%$, for two seasons respectively.

Method Alpatiev with an unchanged bioclimatic coefficient of 0.65 can be used in calculating the total evaporation as a whole during the growing season. It cannot be used to determine the water consumption of carrots for decades in the watershed areas of the Moscow region on sod-podzolic soils.

When calculating the total evaporation of carrots by the method of Ivanov, the deviation of the calculated water consumption from the actual one is equal from $0.8 \%$ to $22.1 \%$ for first season and $8.9 \%$ to $41.5 \%$, for second season. The application of the method of Ivanov in the conditions under consideration is impossible, since it does not take into account the biological characteristics of carrots and soil moisture in the calculation layer.

Estimated values of carrot water consumption by the method of Klatt give an error were $11.2 \%$ and $27.4 \%$ in general for the growing seasons respectively. This technique can be applied in conditions of research in general for the growing season. At the same time, large deviations (up to $44.4 \%$ ) were noted in determining the total evaporation for ten-day periods, which are associated with not taking into account the biological characteristics of carrots for these periods.

The Blaney-Kridll method during the growing season gives an error in the total evaporation of carrot at $11.2 \%$ and $9.9 \%$ for the growing seasons respectively. Deviations are more significant during the ten-day periods and reach 58.3\%. Formula Blaney-Kridll can be used to determine the total evaporation in the conditions of research in general during the growing season. It cannot be used to determine the total evaporation for decades due to the lack of biological coefficients for a given region and dining carrots, as well as low accuracy.

Total evaporation calculated by the method of Tsipris, diverges from the actual values by $11.4 \%$ and $29 \%$ for the growing seasons respectively. The discrepancies of the average tenday calculated values with the actual ones reach $53.2 \%$ and $53.1 \%$ for two seasons respectively. It follows from this that the method Tsipris, by definition, the total evaporation of dining carrots for decades in the conditions of research, cannot be recommended. 


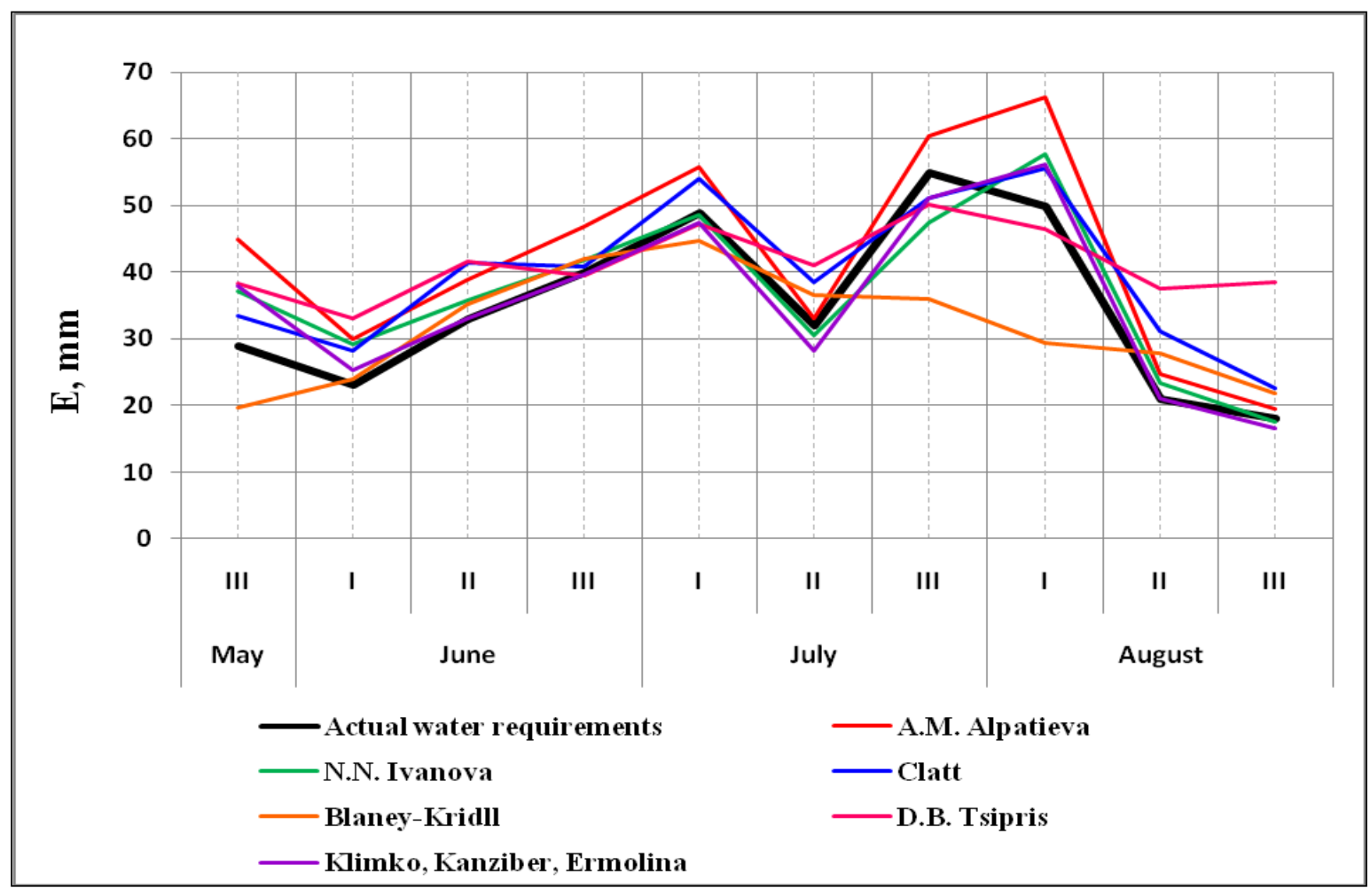

Figure (1): Comparative analysis of actual water requirements data of Carrot and calculated by different methods, Alpatiev, Ivanov, Clatt, Blaney-Kridll, Tsipris and others. Klimko, Kanziber, Ermolina, for the first season.

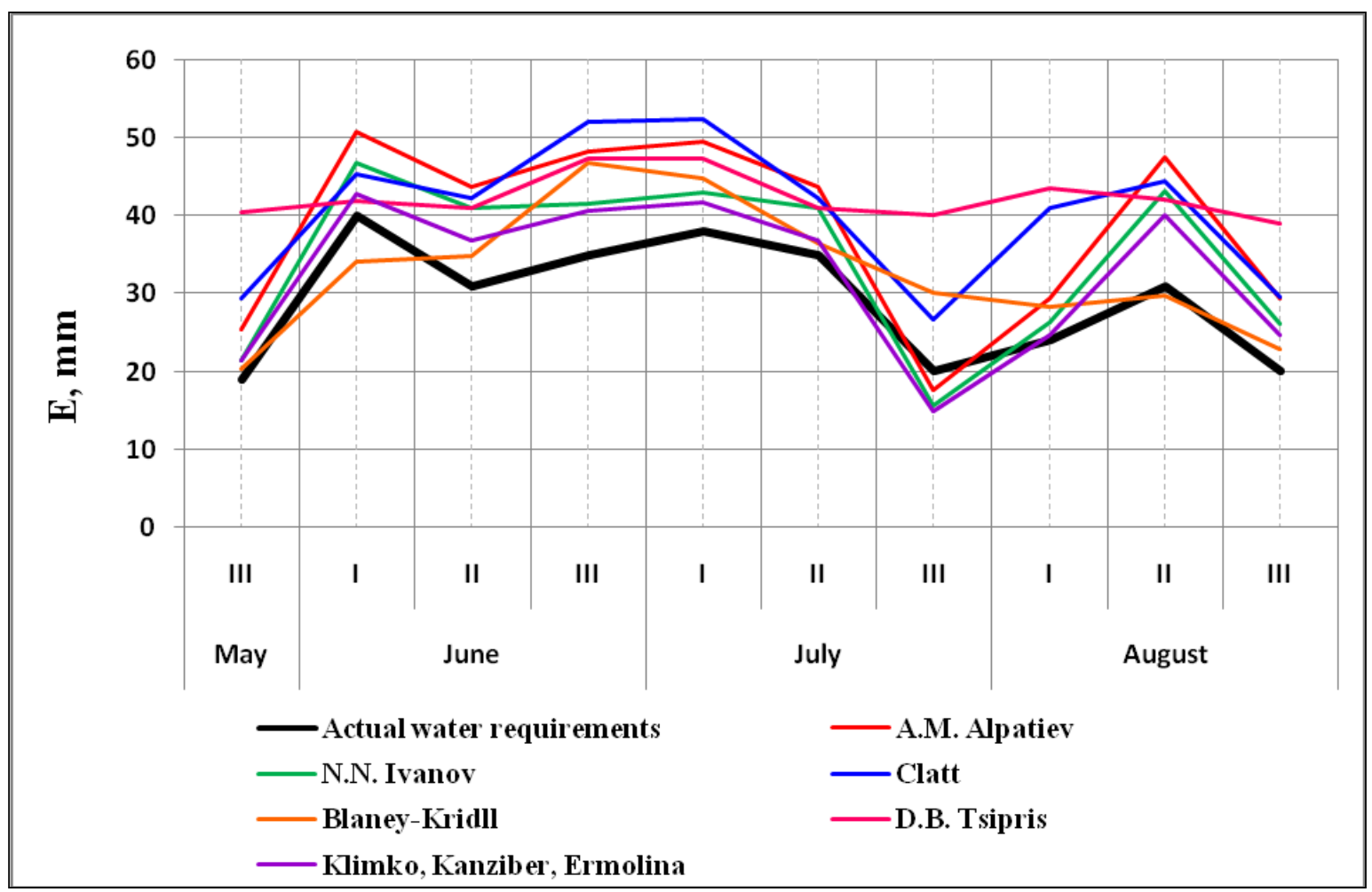

Figure (2): Comparative analysis of actual water requirements data of Carrot and calculated by different methods, Alpatiev, Ivanov, Clatt, Blaney-Kridll, Tsipris and others. Klimko, Kanziber, Ermolina, the second season. 
Klimko, Kanziber and Ermolina, recommend calculating the total evaporation of vegetable crops by the sum of the average daily air humidity deficits and the regression coefficient. The calculation data of the method under consideration give the following discrepancies with the actual ones $23.6 \%$ and $34.7 \%$ for two seasons, respectively, for ten-day periods. A comparative analysis allows us to conclude that we recommend the method of Klimko, Kantsiber, Ermolin for calculating the total evaporation of carrots for decades is not possible.

Decade values of the total evaporation of the carrots are necessary for us to justify the calculated irrigation regime. However, the calculation data and comparative analysis showed that the methods we examined did not satisfy the requirement of the necessary accuracy when cultivating carrots and sprinkler irrigation under the conditions of scientific research. Therefore, it is necessary to obtain a formula for calculating the total evaporation of carrot for sod-podzolic soils of the watershed areas of the Moscow Region under sprinkler irrigation.

In the future to calculate the regime of sprinkler irrigation we need to determine the water requirements for the periods 10 days. As the results of calculations and comparative analysis none of these methods we have in Russia, when grown carrot with sprinkler irrigation does not provide the required accuracy of the results. That is they do not take into account the root zone moisture content of the soil. In connection which there is a need to develop a methodology for calculating water requirement in Russia under sprinkler irrigation with the root zone soil moisture.

In (Pchyolkin and Zimin, 2003), (Pchyolkin, 2015) analyzed the various forms of relationships between water requirements and temperature and relative humidity. The relationship showed a function having the following formula:

$$
\mathrm{E}=\mathrm{ads}
$$

Where:

E - Crop water requirements, $\mathrm{mm} /$ decade;

ds - Deficits of air humidity, mbar,

$a, b-$ Empirical coefficients of the regression equation.

By using experimental data through the growing seasons of carrot (soil moisture content, temperature, relative humidity and the amount of average daily deficits humidity) by the method of mathematical statistics was obtained by the regression equation between water requirements and the amount of average daily deficits humidity and shown in figure 3 and table 6.

$$
E=1.06 \mathrm{ds}^{0.86}
$$

Table (6): Empirical coefficients a and b.

\begin{tabular}{ccc}
\hline Crop & A & b \\
\hline Carrot & 1.06 & 0.86 \\
\hline
\end{tabular}

Correlation coefficient for this connection was $0.959 \pm 0.073$. This means that in $91.9 \%$ of the water requirement of carrot variations in these conditions due to variations in deficit air humidity. 
It should be noted that the static ranks include monitoring water demand periods when the carrot were well developed and the soil moisture content was adequate (100\% ETc) that is when water requirement is equal to the potential evapotranspiration. If these rules are included in the calculation of the data from 18 May to 08 September and excluded the value of water requirements beginning and end of the growing season.

The formula (5) was obtained for the calculation of water requirements of carrot without their biological characteristics. Biological characteristics of agricultural crops in the fact that in the initial period of vegetation is not sufficiently developed root system and foliage. So prevalent physical evaporation from the soil surface above the transpiration. At the end of the growing season plants are aging and the intensity of water use falls.

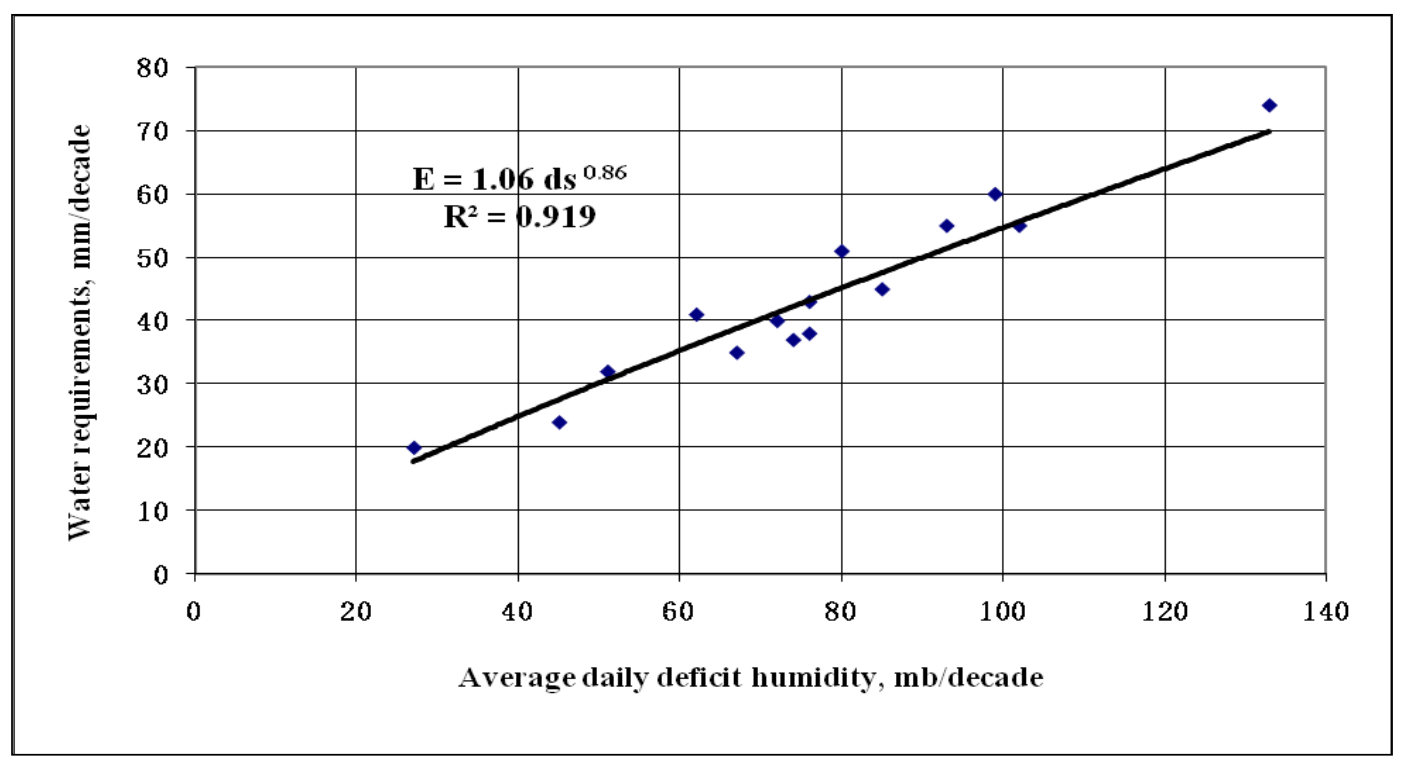

Figure (3): The relationship between water requirements and the amount of average daily deficit humidity for growth seasons.

At the beginning and end of vegetation dominated by physical evaporation of transpiration water requirement is lower than in the period when transpiration dominates. These biological features carrot considered entering into formula (2) biological coefficients are determined from the equation:

$$
\mathrm{Kc}=\frac{E_{\text {Act. }}}{E_{\text {Calc. }}}
$$

Where: $E_{\text {Act. }}$ : Actual water requirements calculated by water balance, mm/decade.; $E_{\text {Calc.: }}$ : Calculated water requirements calculated by formula (5).

As the results of the calculations the values of the biological coefficients depend on the phase of plant development. By using the experimental data for the biological coefficients carrot between irrigation intervals were composed of 30 rows of static members to determine the relationship between the relative time and crop coefficient, the regression equation was obtained the equation for calculation crop coefficient of carrot through growth season.

$$
\mathrm{K}_{\mathrm{C}}=0.687+0.128 \mathrm{t}_{\mathrm{r}}-0.011 \mathrm{t}_{\mathrm{r}}^{2}
$$

Where: $t_{r}-$ decade number $($ decade $=10$ days period $)$ 
The correlation coefficient of this relationship for carrot crop is $0.959 \pm 0.079$ and the determination coefficient is 0.921 . This means that in $99 \%$ of cases, fluctuations in the water consumption of the carrot in the conditions under consideration are due to fluctuations in the air humidity deficit. This shows the close relationship between the estimated and actual values of the crop coefficient. The results of calculations by equations (7) were summarized in figure 4 and table 7.

When introduced into the formula (5) the importance of crop coefficient regression equation takes the form (mm):

$$
\mathrm{E}=\mathrm{K}_{\mathrm{C}} \mathrm{ads} \mathrm{s}^{\mathrm{b}}
$$

Where: $\mathrm{K}_{\mathrm{C}}-$ Crop coefficient.

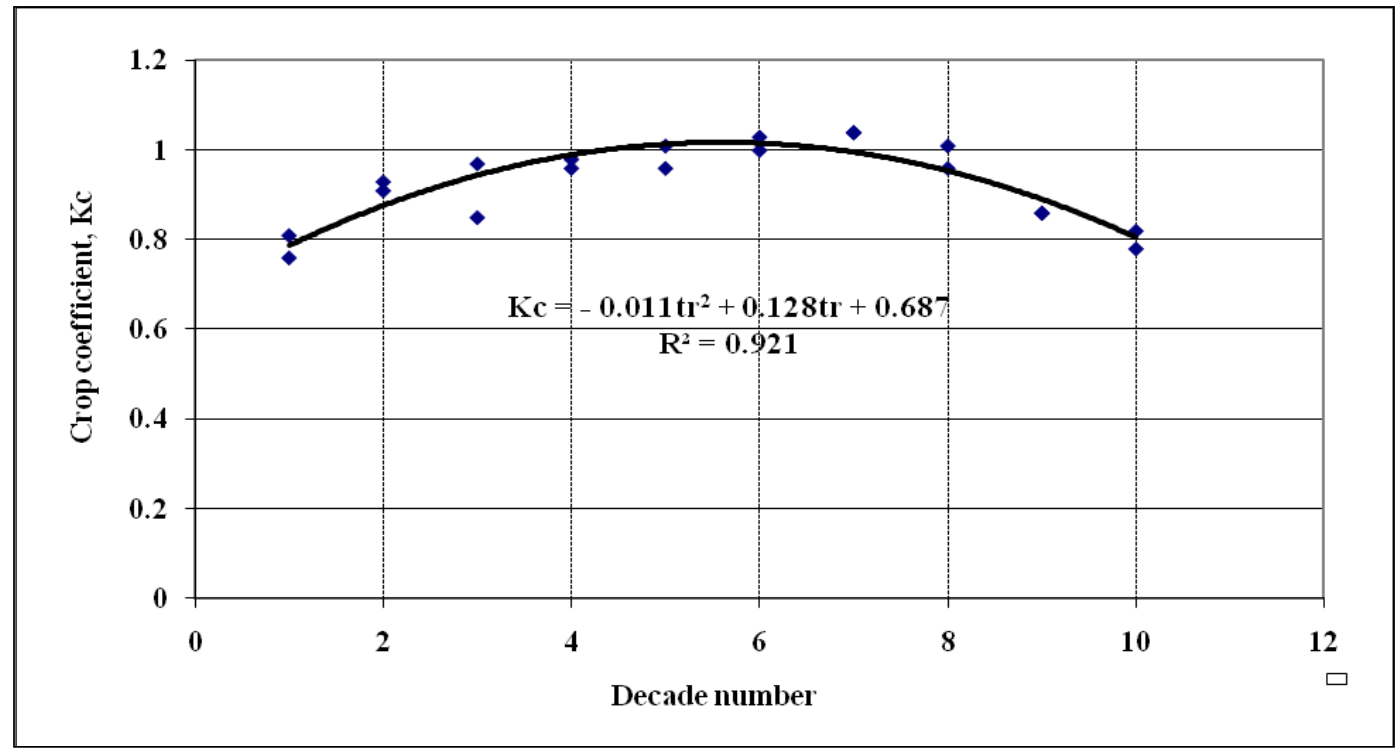

Figure (4): Relationship between crop coefficient of carrots and decade number for growth seasons.

At determining water requirements should be considered all the area that is in the field of sprinkler irrigation. The wetting pattern under sprinkler will vary depending on their specifications. But it is impossible to develop the formula for the calculation of water requirements for each type of sprinkler. Based on this fact it was decided to enter into the formula $(8)$ factor $\left(\mathrm{K}_{\mathrm{F}}\right)$ which takes into account the wetting pattern under sprinkler.

Table (7): Average decade values of crop coefficient of carrots for growth seasons.

\begin{tabular}{ccccccccccc}
\hline Decade number & 1 & 2 & 3 & 4 & 5 & 6 & 7 & 8 & 9 & 10 \\
\hline Crop coefficient & 0.79 & 0.92 & 0.91 & 0.97 & 0.99 & 1.02 & 1.04 & 0.99 & 0.86 & 0.80 \\
\hline
\end{tabular}

The final formula for the calculation of water requirements for carrot under sprinkler irrigation system will be the following:

$$
E=K_{F} K_{C} a d s^{b}
$$

Where:

$\mathrm{E}$ : Crop water requirements, $\mathrm{mm} /$ decade;

$\mathrm{K}_{\mathrm{F}}$ : Coefficient depending on wetting pattern under sprinkler,

$K_{C}:$ Crop coefficient. 


\section{CONCLUSIONS}

In the future to calculate the regime of sprinkler irrigation we need to determine the water requirements for the periods 10 days. As the results of calculations and comparative analysis none of these methods we have in Russia, when grown carrot under sprinkler irrigation does not provide the required accuracy of the results. That is they do not take into account the root zone moisture content of the soil. In connection which there is a need to develop a methodology for calculating water requirements in Russia under sprinkler irrigation with the root zone soil moisture.

The final formula for the calculation of water requirements for carrot under sprinkler irrigation system will be the following:

$$
\mathbf{E}=\mathbf{K}_{\mathbf{F}} \mathbf{K}_{\mathbf{C}} \mathbf{a} \mathbf{d s} \mathbf{s}^{\mathbf{b}}
$$

\section{ACKNOWLEDGEMENTS}

Authors wish to thank Russian State Agrarian University, Moscow, Russia for him assistance to complete this work and also thanks for the revision and formatting of this article.

\section{REFERENCES}

Aleksankin, A.V. (1980). Land reclamation in the non-chernozem zone of the RSFSR /Alekskander Vasilievich Aleksankin, Nikolai Ilyich Druzhinin. M.: Kolos,1980- 288 p.

Alpatiev, A.M. (1971). To the rationale for the formation of irrigation norms using the bioclimatic method for calculating total evaporation /A.M. Alpatiev.,V.P.Ostapchik //Land reclamation and water management.1971- Issue 19- S. 13-17.

Averyanov, S. (2015). Soil water management in reclaimed agricultural lands. Russia: RTSAU Publications.

Badr A.E.; Bakeer G.A.; El-Tantawy M.T. and A. H. Awwad. (2006). Sprinkler and trickle irrigation affected by climatic conditions in upper Egypt. Misr J. Ag. Eng., 23(2): 346361.

Blaney-Kridll, (1986). Rational use of the FAO Blaney-Criddle formula. J. Irri. Drain. Eng. Div., 122 (2), 139-155.

Dokuchaeva V.V., (2002). Soils of the Moscow region and their use / Collective of authors in 2 volumes. M.:Soil Institute. V.V. Dokuchaeva, 2002 - 300 p.

GOST R 28268- (2013). The soil Methods for determining moisture, maximum hygroscopic humidity and moisture of sustainable wilting of plants. - M .: Standartinform, 2013. 9 p.

Ivanov, N.N. (1954). On the determination of the value of evaporation / N.N. Ivanov // Proceedings of the All-Union Geographical Society - 1954. - v. 86. issue 2.- S. 189196.

Jacobs, H. S.; Reed R. M.; S. J. Thien and Withee. (1971). Soils laboratory exercise source book. Am. Soc of Agron. Mandison, Wisconsin. 
Klatt, F. (1970). Die Steuerung den Beregnung nach dem Beregnungsdiagramm./ F. Klatt // Feldvirtschaft. № 4- P.164-165.

Klimko A.I., Kanziber Yu.A. and Ermolina L.M., (1990). Development of environmental measures for the regulation of the water regime on drained floodplain lands: Scientific report of the NIS MGMI - No. State. register 0186.011740.- M.: MGMI, 1990. - 331 p.

Klute, A. (1986). Methods of soil analysis. Part 1. Physical and mineralogical methods (2nd edition). American Society of Agronomy Inc., Madison, Wisconsin, USA.

Kruzhilin, A.S. (1977). Biological features and productivity of irrigated crops / A.S. Kruzhilin- M.: Kolos, 1977. 301s.

Pchyolkin V.V. and Zimin F.M, (2003). Water regime of crops on drained floodplain lands. "Problems of ecology and life safety in the 21st century." Materials international. Scientific Pract. Conferences. Vol. 4, MA, MAEBP, 2003., p. 136 - 138.

Pchyolkin, V.V. (2013). Water regime of drained floodplains (p. 253). Moscow: Koloss Publications.

Pchelkin, V.V. (2015). Irrigation regime for carrots on sod-podzolic soils of the watershed areas of the Moscow region / V.V. Pchelkin, S.O. Vladimirov // Environmental Engineering. - 2015. - No. 5. - S. 78-82.

Romanova, E.N., Mosolova, G.I., and Beresneva, I.A. (1983). Microclimatology and its significance for agriculture/E.N. Romanova, G.I. Mosolova, I.A. Beresneva - L .: Gidrometeoizdat, 1983. p. 245.

Shelkovkina, N.S.(2004). Water consumption and irrigation regime of soybeans when applying mineral fertilizers in the Amur region: author. diss. ... Cand. those. Sciences .: 06.01.02 / Shelkovnikova Natalya Sergeevna. - Volgograd, 2004 .- 24 p.

Shuravilin, A.V. (2006). Melioration: a training manual/A.V. Shuravilin, A.I. Kibeka. - M.: ECMOS, 2006. 944 p.

Shuravilin, A.V. (2013). Soil water balance and onion water consumption depending on the level of moisture during drip irrigation in Nepal. / A.V. Shuravilin, T.I. Surikova, Bhandari // Environmental Engineering. - 2013. - No. 3. - S. 28-32.

Smith. M. (1992). CROPWAT- a computer program for irrigation planning and management. FAO. Irrigation and Drainage paper 46. Rome.

Tsipris, D. B. (1973). Irrigation in the Non-Chernozem Zone/DB Tsipris- M.: Kolos, 1973 $192 \mathrm{p}$.

Vaneyan, S.S., and Lesser, A.M. (2010). Irrigation regime, methods and techniques for watering vegetables and melons in various zones of the Russian Federation: manual / S.S. Vaneyan, A.M. Smaller ones. M.: GNU All-Russian Research Institute of Vegetable Production, 2010- 82 p.

Zimin, F.M. (1989). Justification of the regime of irrigation of white cabbage on the drained lands of the floodplain of the river. Dubna: author. disscand. tech. Sciences: 06.01.02/Zimin Fedor Mikhailovich. - M., 1989 - 19 p. 


\section{الاحتياجات المائية لمحصول الجزر مع الري بالرش تحت الظروف الروسية}

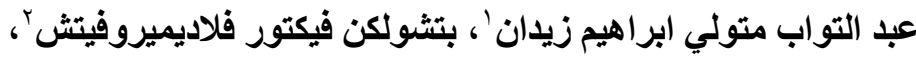

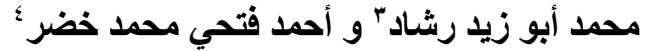

' أستاذ مساعد هنسة الري و الصرف ـ قسم الهندسة الزر اعية ـ كلية الزر اعة ـ جامعة الزقازيق ـ مصر. r أستاذ استصلاح الار اضي و الري ـ الجامعة الزر اعية الروسية ـ موسكو - روسيا.

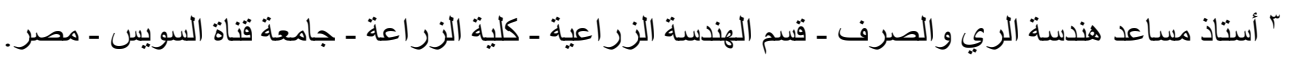

\begin{tabular}{|c|c|}
\hline 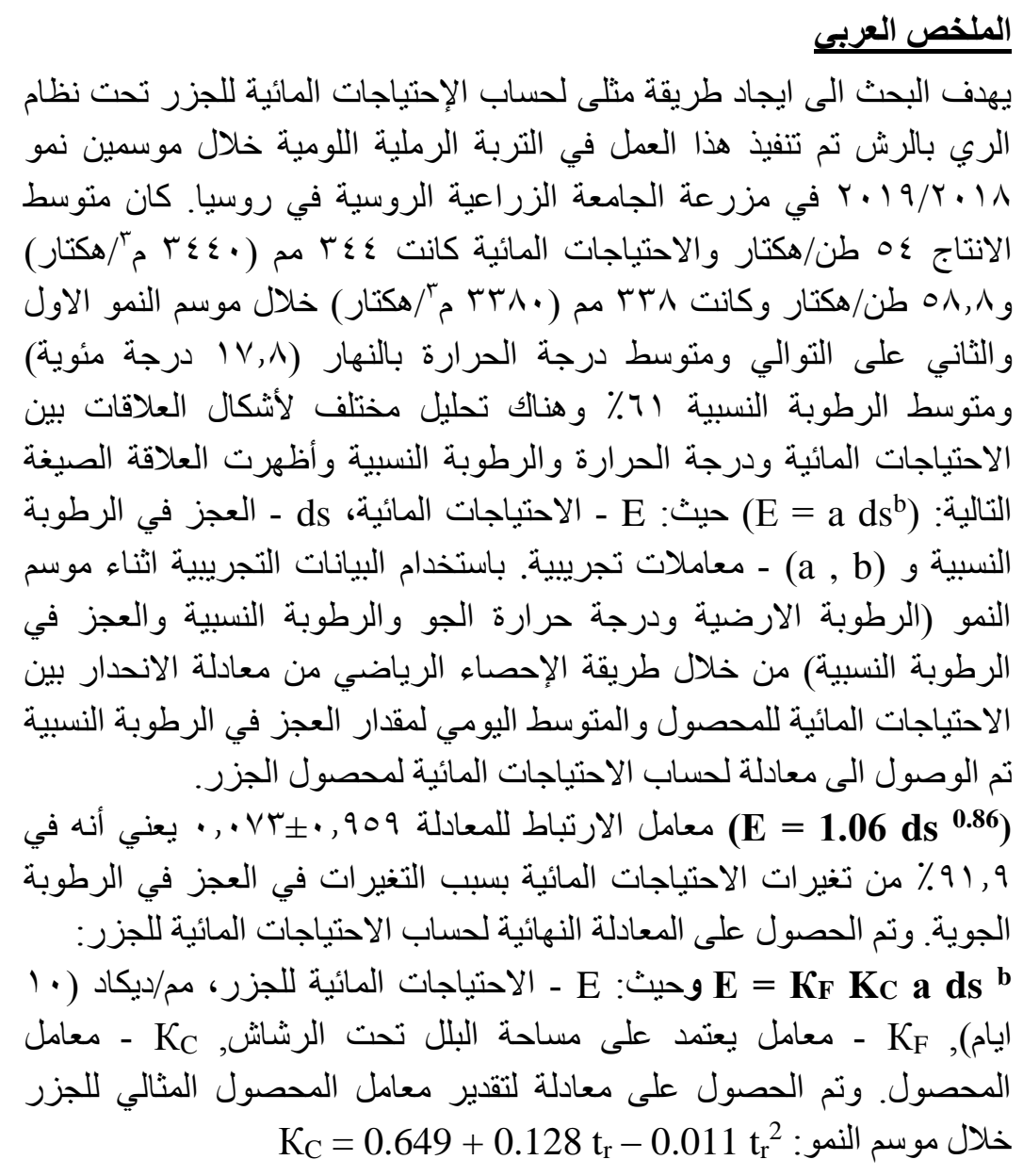 & 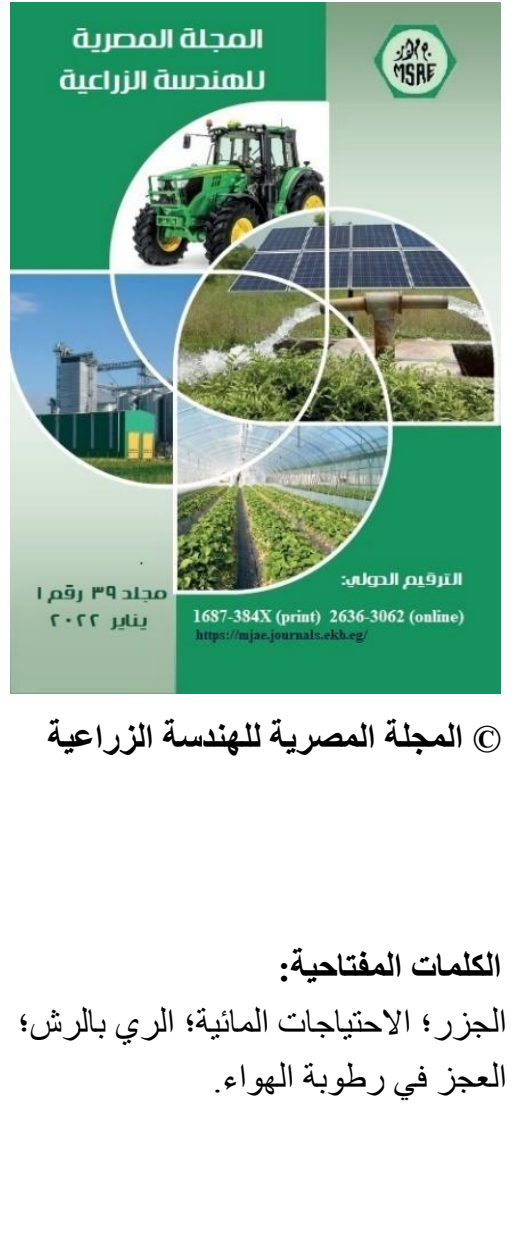 \\
\hline
\end{tabular}

